\section{OROGENICS OF THE GREAT BASIN}

WHEN, about forty years ago, the members of the Fortieth Parallel Survey leisurely traversed the mile-high Great Basin between the lofty Rockies and the Sierra Nevada, their impressions on the configuration of the mountain ranges were that there was chiefly folding of the Appalachian type wherein the synclines were deeply and almost completely filled with illy transported rock-waste from the neighboring highlands.

A decade later, corps of other governmental surveys, passing through this part of the country, put an entirely different interpretation on the origin of the rugged desert ranges. Novel as well as brilliant was the conception that these mountains were recently tilted faultblocks of gigantic size. This fancy led to another brilliant idea-the hypothesis of isostatic compensation, whereby there is ready response to the transference, of eroded rock materials from one point to another, loading areas sinking and unloading areas rising.

Curiously enough when the isostatic hypothesis came to be critically tested in the field no faults bounding the orographic blocks were discoverable. More than a third of a century passed since the idea was first promulgated and yet no one appeared to find impeachable evidences of the alleged crustal ruptures. A governmental expedition, especially fitted out to solve the problem and headed by the author of the hypothesis himself, failed to establish the claim or to publish the desired data. Many of the so-called faultscarps which were described as marking the basin ranges proved not to be fault phenomena at all, but merely characteristic features of normal eolic erosion at the level of maximum activity. Other investigators searching especially for the assumed faults found not major lines of this character bounding the present mountains but instead discovered dislocation phenomena in the most unexpected situations -far out on the smooth intermontane plains. There was manifestly no genetic relationships existing between mountain profile and geologic structure. On the whole the proposed hy- pothesis of Basin Range structure proved to be singularly unsupported by observation.

In the meanwhile testimony of another kind abundantly accumulared bearing upon the problem. When the presence of faulting was all but completely discredited, it was shown that although extensive rupturing actually occurred in the region it was mainly relatively ancient. It long antedated the time when the present mountains took form.

There is, however, a third possible explanation of the faulting phenomena displayed in the Great Basin. The major faulting of the region may not be of the normal gravity type as is so commonly supposed. It may be mainly of overthrust character. In support of this suggestion, as a general proposition, there are a number of considerations besides the almost conclusive theoretical one. A remarkable circumstance is that some of these thrustplanes in the desert ranges are often mistaken for lines of unconformities. This may be the real reason why so few normal faults are found bounding the mountain blocks. The overpowering influence of the normal fault idea has much to do with the general misinterpretation of Basin Range orogeny.

Concerning the tectonic genesis of the desert ranges we shall now probably have to give up our brilliant conceptions of mountain blocks floating on the liquid interior of the earth much after the fashion of ice-cakes in a river at time of spring break-up. What the substitute shall be may not yet be perfectly clear. Mountains of circumdenudation through the differential activity of eolic erosion under the stimulus of the aridity and over a region previously effected widely by overthrust movements seems more nearly in accordance with the larger aspects of the conditions presented. At least the extent of the overthrust activity is worthy of the most careful consideration and severest test in the field.

\section{Oharles Keyes}

\section{DISTRIBUTION OF THE FRESH-WATER MEDUSA, CRASPEDACUSTA, IN THE UNITED STATES}

IN ScIence, November 8, 1907, the writer published a brief account of the applearance 
of this interesting medusa in this country, and in the Biological Bulletin of April, 1908, described in some details the history of the case, and evidence of its identity with Limnocodium sowerbii of Europe. These were the first accounts of this species in the United States, and its occurrence at that time in the aquarium of a green-house in Washington, D. C., used by its owners for propagating exotic tropical plants, suggested its possible introduction by means of such plants. But the assurance of the proprietor that only the seeds of such plants were imported threw serious doubt upon such an inference.

In SoIence, December 15, 1916, Professor H, Garman reported a most interesting occurrence of this medusa in Benson creek near Frankfort, Kentucky, and later the present writer received from Professor Garman specimens which were identified as the same as those formerly described from the Washington aquaria. Here in this fresh-water stream, a small tributary of the Kentucky river, far removed from any possible source of artificial introduction, the occurrence of "millions" of these medusæ, at once utterly discredited the earlier asumption of distribution by artificial means from tropical sources of its assumed habitat.

On October 4, 1919, I received from Professor F. Payne of Indiana, a letter announcing the finding of these medusæ in a lake in northern Indiana, and on the following day an official communication from the Bureau of Fisheries announcing its receipt from "Boss Lake" near Elkhart, Indiana, of medusæ presumed to be the same as those formerly described from Washington, D. C., and later from Kentucky, as cited in the above paragraph, and this was easily verified on the receipt of excellent specimens preserved in formalin. These were accompanied by copies of letters from Mr. J. C. Boss, owner of the small lake mentioned above. This lake was constructed by Mr. Boss, and the following abstract from his letter to the Commissioner of Fisheries will be interesting.
Boss Lake resulted from the overflow caused by the building of a large dam on the St. Joseph River. Our family owned and operated a brick yard at a point on said stream the backwater of which flooded so large a portion of the clay bank that it ruined it for commercial purposes. A large dyke was built between the clay pit and the river, reinforced by puddled clay to make it as nearly as possible water tight so we might raise the waiter to a height of about seven or eight feet above flood tide of the river; this purpose was accomplished effectively and the lake so stands to-day. The lake contains about four acres, is fed by surface spring water and an artesian flowing well, the level remaining constant.

This lake has been stocked with Black Bass supplied by the Bureau of Fisheries, and Mr. Boss states "there have never been any plants from other lakes introduced or planted in this, especially not of exotic species," though it abounds in native aquatic grasses, he states.

A most interesting feature comes to light in the data furnished by Mr. Boss, namely, that the medusæ were first observed one year ago, then very few in number. This year about August first they again appeared and in greater numbers, and during "ten days we have seen millions, they come to the surface on warm sunshine days." That is, not only have these formerly supposed tropical medusæ established themselves in northern waters, and persisted over winter, but have greatly multiplied during the second year, hence breed freely under these conditions. Those found in the Kentucky creek apparently disappeared very suddenly, as did those in the Washington aquaria as reported in my former papers, on the approach of cooler weather; and in neither of these localities have they reappeared, so far as known, Professor Garman stating his purpose to closely follow up the matter the following year having made no further report.

These several occurrences of this medusa in the fresh waters of this country clearly proves that it has become an indigenous faunal factor and clearly able to perpetuate itself, and further that it has not at any time been introduced through artificial means from remote regions. It still remains prob- 
lematic as to the precise processes of its distribution, propagation and life history. But among the present material numerous female specimens occur, a feature not previously described. Hydroid phases of the organism have been but vaguely suggested. ${ }^{1}$

\section{O. W. HARGITT}

SYracuse UnIVERSITY, October 11, 1919

\section{SCIENTIFIC BOOKS}

Observations on Living Lamellibranchs of New England. By Edward S. Morse. Proc. Boston Soc. Nat. Hist., Vol. 35, no. 5, July, 1919, p. 139-196, Figs. 1-48. The state of New York once published an imposing quarto report on its mollusca of which the only feature remaining in the memory of the present reviewer (except the minus value of that part supposed to cover the nudibranchs) is an exquisite hand-colored engraving, nearly life size, of a common "horse-mussel" shell showing every accidental scratch, every, adhering bit of alga or barnacle, every growth line, each abraded spot, a piece of dried mud and a chipped place on the margin, with more than photographic minute accuracy. It was impressive. It was costly. It was uninspired, It was valueless.

Professor Morse's little paper is in every respect the opposite. Its 57 octaro pages and 48 rough outline text figures probably cost all together a small fraction of what that gorgeous portrait of a mussel shell alone cost the state of New York. But those pages add more to our knowledge of American molluses than the entire imposing quarto and each simple drawing is a work of true art. Of some it is not too much to say that, while drawn for the sake of the soft parts alone, and practically confined to outline, they constitute the most characteristic extant representations of the shells. It must have been his years of intensive study of Japanese

1 Since the foregoing notes were written $I$ have received later statements from Dr. Payne that he has made several trips to the lake and has undertaken fuller investigations than are at present possible to me, and will doubtless issue them in due time. pottery that gave Professor Morse full appreciation of the value of subtly correct outlines and the importance of omitting non-essentials, for although his work shows he was already an artist when, he first published figures of molluses fifty-five years ago, and his drawings of living brachiopods have been famous for their vital accuracy, it seems to have been reserved for his return to biology after his Japanese interlude, and for the riper age of eighty-one years, for him to attain the acme of the art of telling with his pencil the most, and the most truly, about an animal in the most simple way.

Although American malacology has, if anything rather more fully than European, recognized" theoretically that the "soft parts" are, after all, the animal that is being studied, and the shell (except as a paleontological marker) of little value except for what it can tell us about that animal, yet in practise it has fallen woefully behind Europe in study of the animal as distinguished from its shell. This is particularly true of the marine Pelecypods. Pilsbry and others, successors of Binney, have elucidated our land snails, while Baker and Walker have thrown a flood of light on our fresh-water Gasteropoda, and Ortman, Sterki and others under the stimulus of Simpson's work on the Naiades have dealt fruitfully with the fresh water Pelecypoda. The marine Gasteropoda have had more scattered attention but on the whole their bolder habits and more varied and striking anatomy have attracted a considerable mass of observation, while the shy and rather monotonous animals of the marine Pelecypoda have been neglected. There have been a few intensive studies of single forms by Drew and others; but Dall and Verrill, whose work on this group outbulks many times over that of all others combined, have handled chiefly fossil or deep-sea or preserved material or else "just shells" as usually sent in by the amateur collector. Thus a large proportion of the present paper consists of novel observations while the graphic records of those observations are almost wholly novel. One could wish that Professor Morse had 